\title{
CHANGES OF THE CONCEPT OF STATE FINANCE AND SUBJECTS IN SUSTAINABILITY CONTEXT
}

\author{
GINTARAS ČERNIUS
}

Mykolas Romeris University, Vilnius, Lithuania

\section{ABSTRACT}

In a face of global financial crisis that is currently shaking the world, the issue what is the role of a state in its finance management and how each state influences, or can influence, its finance is extremely relevant.

The objective of this research is to identify whether the contemporary approach to public finance and its subjects is suitable for the effective financial management at a state level in present conditions. In order to reach the objective, the research shall examine how the contemporary approach to finance limits possibilities of its management; form new concept of state finance involving private and public finance; and define how the application of new, broader, social partnership based approach, might change financial relationship between a state, citizens, and companies, and how practical application of this new approach might contribute to financial stability of a state. Practical application of the research results would allow saving 2-4 percent on the interest rates for state loans, create better conditions for the development of state economy, and increase financial sustainability of a state.

\section{JEL CLASSIFICATION \& KEYWORDS}

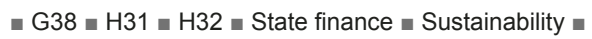

\section{INTRODUCTION}

Contemporary situation provokes a question to what extent and by what measures a state manages, or can manage, its finance aiming to ensure financial sustainability. The question involves harmonization of macroeconomic and microeconomic policies, various political measures, and the involvement of state subjects of various levels in financial management of a state. Some of the economists clearly state that the connection between macroeconomic and microeconomic policies is obvious, and draw the attention that the relationship between subjects in such economic sectors that do not function according to market economy principles should be based on social partnership (Rakauskienè, 2006). In this case, social partnership is assumed as state support to one or another sector or a group of subjects. However, detailed analysis of social partnership based relationship between the subjects of different level does not exist. Therefore, detailed examination how various subjects could possibly interact with each other in order to create sustainable state finance and what role and functions could be plaid by certain participants of state finance system, is extremely important.

According to some economists, scientific literature and legal acts do not distinguish state and public finance, although, obviously, the latter covers monetary relationship between all members of society (Buškevičiūtè, 2008). In result of such approach, the area of state interest is narrowed to financing Public Functions of a state, in other words, formulation and implementation of fiscal policy.

Such narrowing is clearly evidenced defining the mission and objectives of the Ministry of Finance of the Republic of Lithuania. "The Ministry of Finance of the Republic of Lithuania is an executive body, the mission of which is to formulate and implement an effective policy of public finance in order to ensure the country's macroeconomic stability and economic development.

The strategic objectives of the Ministry include formulation of fiscal policy which promotes trust in macroeconomic stability, and to ensure effective and rational management of public funds and European Union foundation. It also ensures development of the financial sector and smooth implementation of other financial measures".

When legal acts dictate such a narrow approach, a state extremely limits its financial management leverages during financial crisis, since it uses the top level subject only (i.e. the state itself) from all subjects that influence the level and the sustainability of state finance. In this case, financial management of a state is limited to traditional monetary and fiscal instruments whose main subject is the state itself. Lithuania can use just few monetary instruments, due to obvious reasons. In addition, according to Stiglitz (2011) "monetary policy, one of the main instruments for managing the macroeconomy, has proved ineffective - and will likely continue to be".

Thus the management of Lithuanian finance shall be based on fiscal instruments only that can hardly help to implement Public Functions with reduced budget revenue.

In critical situation, the state has a very limited arsenal of possibilities - and first and foremost - reduction of expenses intended for public functions. After the reduction of expenses, all is left is to wait until the international system of finance will recuperate and the recovered consumption will raise the economy. This, in its turn, will increase the budget revenue, and sufficient assets could again be assigned for implementation of Public Functions. However, based on Stiglitz (2010) "in Europe, especially Germany, and in some quarters in the US, as government deficits and debt grow, so, too, do calls for increased austerity. If heeded, as appears to be the case in many countries, the results will be disastrous, especially given the fragility of the recover".

If a state due to any reasons cannot or does not want to reduce funding of the Public Functions, it may increase taxes, aiming to compensate the loss of the budget income in such way. However, in case of an economic recession, such method does not help to balance the budget; it rather reduces consumption even more, and the budget income alongside.

One more possibility (which during a crisis is very expensive and limited) - avoiding the reduction of budget expenses and increase of taxes - is to compensate the loss of budget income with debts. But in this case the state faces a problem of deferred taxation, since "bond financing of public spending is deferred taxation, including a deferred excess burden of taxation" (Hillman, 2009). This problem is highlighted by other economists too, they state that consequences of government borrowing force in future to raise taxes sharply and reduce living standards (Stiglitz, 1999).

Thus, in presence of traditional approach to state finance, state essentially can use identified instruments or their combinations aiming to influence state finance or its sustainability. 
The formation of state financial reserve may be attributed to the precautionary measures, which may be used by a state during an economic boom. During a boom, certain amounts of money may be accumulated, which later, if needed, would be used by a state during a crisis to compensate a loss of the budget income.

As the current global situation has shown, these actions do not give an obvious and indisputable effect in order to properly control the state finance in the condition of crisis.

\section{Changes of the concept of state finance}

In order top make it possible to look for alternative possibilities and instruments of finance management, it would be useful to first of all define what should be considered state finance. The concept of state includes people, living in a separate territory, operating companies and government, which performs public functions. Then it is logical to believe that state finance could be considered the entirety of financial resources of all the subjects. Some economists define three categories of finance in a system of state finance: state, municipal, and corporate (state and private enterprises) (Buškevičiūtè, 2008). In our opinion this is not enough; talking about the system of finance, it is necessary to involve household (private) finance. In this case, state finance acquires two features. Firstly, it is the mass of money, circulating in a specific territory of a state. Secondly, it is financial resources belonging to companies and residents and circulating outside the borders of a state.

Speaking broadly, state finance should cover not only public, but also private finance (of companies and residents (households)). This view is presented in Figure 1.

\begin{tabular}{|c|c|c|}
\hline Figure 1: State financ & & \\
\hline Residents & Personal & \\
\hline Household & finance & \\
\hline Companies & Companies & \\
\hline Companies group & finance & State \\
\hline States, & & finance \\
\hline Countries, & Public & \\
\hline Municipalities, & finance & \\
\hline Non-budgetary & & \\
\hline funds. & & \\
\hline Source: Author & & \\
\hline
\end{tabular}

Such expansion of the concept of state finance (state finance is the entirety of public and private finance) enables us to look at the goal of state finance and measures of its implementation completely differently.

The aim of public finance management is to guarantee the stability of state finance, whereas managing state finance a significantly broader goal appears - to guarantee "the nation's welfare" (Jurgutis, 1938). Or, as provided for in the Law on Budgeting of the Republic of Lithuania, "to seek a longterm comprehensive economic and social welfare of the citizens of the Republic of Lithuania". Without specifying how "the nation's welfare" could be measured, we would believe that the presumptions for its existence include:

1. stability of the financial system of the residents (households);

2. stability of the companies' finance;

3. balancing of the public finance.

www.journals.cz/
Each of these elements is quite important to the entire system of state finance.

Stability of the financial system of residents (households) in case of a crisis allows "absorbing" a part of financial charge, which usually comes to the state. It consists of various social expenses related to unemployment, change of qualification and other expenses of similar nature. If a person who has lost the job had sufficient savings and could live for a certain time without applying to the state for financial aid, in certain cases (especially during financial recessions) this would be a significant support for the state.

The stability of household finance can show evidence in various ways; however, the crisis has highlighted its particular essential features and constituent parts. Of course, the main goal of a personal financial system is to guarantee the person's financial safety in different stages of life and in different economic situations. Financial safety may be ensured by using very diverse measures. Firstly, it is guaranteed and sufficient income in order for a resident to satisfy his/her personal needs. Secondly, it is "reasonable" spending for satisfying personal needs. And thirdly, it is insurance against the cases of loss of income. Insurance may be very different, starting from insurance at an insurance company against loss of income and finishing with a specific reserve of money, which would make it possible to live for a certain period in case of loss of income due to any reasons. In this case, financial security of a person could be measured by time which he/she can live using his/her savings without additional sources of income. In case of a crisis, various authors indicate different periods of time. However, typically the recommended minimum reserve is considered such a reserve which enables to survive from 6 months to one year.

It can be stated that a state when managing its finance as the entirety, should be interested that the reserve of the residents intended to survive through the critical case would be as large as possible. Such a resident could "suffer through" a certain period of time during a financial crisis and, as it has already been mentioned, restrain from applying to the state requiring unemployment pay or other allowance, in such a way burdening the system of public finance even more (Table 1).

Table 1: Number of unemployed persons and unemployment pays

\begin{tabular}{|l|l|l|l|l|}
\hline Year & 2008 & 2009 & 2010 & 2011 \\
\hline Unemployed persons (thousand) & 73,4 & 203,1 & 312,1 & 247,2 \\
\hline Unemployment pays (LTL mil.) & 306 & 629 & 492 & 326 \\
\hline
\end{tabular}

Source: Statistics of the State Social Insurance Fund Board of the Republic of Lithuania

Table 1 shows that in 2010 unemployment pays decreased although the number of unemployed persons significantly increased. This happened because of tightening restriction for the unemployment pay in 2009. In this case, two ways are possible: whether unemployed people had savings that might be used for the living or they joined the black economy and obtained illegal income.

In first case, the saying "rich citizens make rich state" acquires a fully realistic meaning because the residents of the state may facilitate the unexpected state's financial problems to quite a large extent. In the second case, the state collects less revenue and experiences greater expenses aiming to restrict the scope of illegal economy. However, financially well-off residents can help the state by lending their finance to the state in order to cover its budget deficit. Data delivered in Table 2 allows concluding that residents possess enough money to significantly reduce the 
state's need for borrowing in foreign markets. Table 2 shows that recently Lithuanian debt mainly consists of the debts to foreign financial institutions. For the last five years, foreign debt makes about 90 percent of the total state debt.

\begin{tabular}{|c|c|c|c|c|c|}
\hline Year & 2007 & 2008 & 2009 & 2010 & 2011 \\
\hline Household deposits & 22,678 & 24,138 & 24,746 & 26,082 & 27,282 \\
\hline $\begin{array}{l}\text { Deposits of private } \\
\text { enterprises }\end{array}$ & 12,881 & 10,605 & 11,404 & 13,403 & 14,475 \\
\hline Total deposits & 35,559 & 34,743 & 36,15 & 39,485 & 41,757 \\
\hline $\begin{array}{l}\text { General } \\
\text { Government Debt }\end{array}$ & 16,697 & 17,375 & 27,106 & 36,589 & 38,908 \\
\hline Domestic Debt & 1,15 & 1,432 & 2,748 & 2,887 & 3,119 \\
\hline non-financial sector & 32 & 174 & 322 & 358 & 319 \\
\hline Financial sector* & 1,08 & 1,195 & 1,328 & 1,693 & 1,918 \\
\hline other creditors & 38 & 63 & 1,098 & 836 & 882 \\
\hline Foreign Debt* & 15,547 & 15,943 & 24,358 & 33,702 & 35,789 \\
\hline $\begin{array}{l}\text { International } \\
\text { development } \\
\text { organizations }\end{array}$ & 322 & 303 & 2,909 & 4,011 & 4,027 \\
\hline other creditors & 10,904 & 10,859 & 16,135 & 22,92 & 24,088 \\
\hline \begin{tabular}{|l|} 
Part of domestic \\
debt from foreign \\
financial sector
\end{tabular} & 4,321 & 4,781 & 5,314 & 6,771 & 7,674 \\
\hline \multicolumn{6}{|c|}{$\begin{array}{l}\text { * Domestic and foreign debts are recalculated taking into } \\
\text { account that at least } 80 \text { percent of Lithuanian financial sector is } \\
\text { made of foreign banks. }\end{array}$} \\
\hline \multicolumn{6}{|c|}{$\begin{array}{l}\text { Source: statistics of the Ministry of Finance of the Republic of } \\
\text { Lithuania; The Lithuanian Department of Statistics }\end{array}$} \\
\hline
\end{tabular}

Whereas borrowing in foreign financial markets results in significantly higher interest rates than borrowing from citizens, research of some economists allow maintaining that domestic borrowing from residents would save 1.749 million LTL (Jasinavičius et. al., 2011).

Such situation would be doubly useful because the state would get money to borrow and the residents would receive additional income in the form of interest.

The goal of the financial system of companies is to guarantee that a company will continue its activity for quite a long time as well as to guarantee that the owners of the company would receive financial benefit. Stable financial system of a company enables the company to survive through the period of economic recession without significant shocks. The main objective of company's finance is to guarantee such income which would enable a company to earn profit, pay dividends and increase its value. The income may be received from clients in form of payment for the company's merchandise or, in case of crises, using in advance accumulated reserves. Such a company is able to survive an unfavourable period without significantly reducing workplaces or salaries of the employees, and also not transferring its financial problems to the state (Table 1). Moreover, the companies which have sufficient resources could lend to the state during the time of recession when the budget revenue is not sufficient for the funding of the Public Functions (Table 2). In such an event, it would be beneficial for the state to borrow cheaper in the internal market and for the companies to receive additional guaranteed income.

The goal of the public finance system is to guarantee stable funding of public needs. According to Garry Schinasi (2007) any financial system is stable if the system is capable to perform three key functions: 1) the intertemporal allocation of resources from savers to investors and the allocation of economic resources generally; 2) the assessment, pricing, and allocation of forward looking financial risks; 3 ) and the absorption of financial and real economic shocks.

Stability of public finance system in practice may be ensured by various methods. During a period of economic boom, public finance is maintained by the growing budget income; therefore it would seem that at that time it is not necessary to take any active measures in order to ensure the stability of the system. This is a deceptive attitude because right during such a time period, the foundation for the stability of the public finance system must be laid. A surplus budget may be formed only during an economic boom and, sequentially, the financial reserves which can be used during an economic recession. If this is not be done in time, after the economy slows down only two possibilities remain to compensate the reduction in the budget revenue: to increase the taxes to companies and residents or to borrow domestically or abroad. Lithuanian "need for borrowing and costs related to it of 2009, 2010, and 2011 were mainly conditioned by the fact that temporary budget surplus of 2006-2008 was converted to permanent obligations to pay bigger social benefits (maternity benefits, pensions) and salaries (to teachers, medical employees, state officers). During the economic recession, budget revenue significantly decreased and the absence of reserve accumulated during the economic boom forced to finance budget deficit (the difference between budget revenue and expense) in a way of borrowing. The greatest need for borrowing was noticed in 2009"(Ministry of Finance of the Republic of Lithuania, 2011)

The scope of the borrowing problem described above is well seen from planned allocation of 10.3 billion LTL that is intended to borrow in 2012. One part of this amount (6.1 billion LTL) will be spent for the redemption of 2002 issue of Eurobonds (renewed in 2006) and refinancing of other debts. Covering the deficit (difference between revenue and expense) of Public Finance will require borrowing of 3.3 billion LTL; 2.7 billion LTL whereof (taking into account state's obligation to pay bigger pensions) goes to the State Social Insurance Fund Board and 600 million LTL will be left for financing state budget deficit. (Ministry of Finance of the Republic of Lithuania, 2012).

The greatest concern lies in the amounts borrowed for financing bigger pensions that increased in previous years. It shows that current social insurance system is not able to satisfy its current financial needs with current resources. This essentially means, that solving social problems is left for future generations, thus, based on Hillman (2009), it is "intergeneration tax sharing".

One more possibility exists in order to survive an economic recession: reduction of budget expenses (i.e. the funding of the Public Functions). This quite effective option has both positive and negative consequences. Besides, reduction of budget expenses, especially in the social domain, is a very unpopular measure from the political perspective and may cause social disturbances.

Keeping in consideration the currently dominating narrow approach to state finance, in fact there are all possibilities to manage finance to the extent of state. This is because the traditional approach does not foresee the management measures which cross the limit of fiscal and monetary policy.

If we treated state finance as suggested above (including more objects and subjects), it would be possible that additional options appeared, which were invisible and unused under the present conditions. 
Back to the concept of the nation's welfare, it could be stated that the goal of the state finance policy should cover a lot broader target area, rather than just a momentary budget "rescue" goal. The state should be interested in:

1. prosperity of citizens, their savings and the safety of such savings;

2. prosperity of companies and their ability to survive through a period of financial recession without transferring their problems to the state (unemployment);

3. accumulation of state reserves and formation of rules regarding their allocation.

\section{Relationship of state subjects in financial sustainability context}

The relations between the state and the citizens in the area of finance could be based on the principles of equality. In other words, both the state and its citizens could be considered social partners, who adequately perceive the situation, are able to independently make the considered financial decisions and perceive the consequences of such decisions. Every social partner (both the state and its every citizen) should assume liability for their decisions and actions. This way, the citizens who lose their money due to unsuccessful financial operations should not expect and require compensation from the state. However, the state in its turn should not treat its citizens in such way that the latter would not have the option of choice.

If the state and its citizens were considered equal social partners in the area of finance, the state would be interested in having prosperous citizens who are capable of managing their own personal (household) finance. Therefore, for the beginning it would be purposeful to encourage the financial intellect of the residents in all possible ways, starting already in school. In Lithuania, we currently have a paradoxical situation, when the commercial banks rather than the state started taking care of the financial education of the people.

When the state and its citizens become partners, the state should become interested in informing its residents about the possible future perspectives in the areas of finance and economy in order to enable the citizens to make decisions related to finance and investments. For example, knowing that in 2012-2013 the state will have to borrow additional amounts in order to redeem previously issued bonds residents may have planed to invest their excessive finance in government securities. The state, on its turn, might use domestic financial resources and reduce the pressure to borrow in foreign markets, if the situation for such borrowing is not favourable.

In terms of the relations between the state and its citizens, the priority should be given not only to education in the area of finance, but also to various programs which encourage saving, alongside with the information on every household's reserve "against a rainy day". At this moment in Lithuania, according to the data of different surveys, 25 to 50 percent of people do not have any savings (The Securities Commission, 2009). These residents, if they happen to lose their jobs, will be the first applicants for social support from the state because they just will not have any other choice.

On the other hand, according to the data of the same surveys, most people who have one or other kind of savings keep them in cash or as deposits in the banks (Table 2). The state, if needed, could have used these internal resources instead of expensively borrowing abroad. Currently, Lithuania makes positive progress using savings of residents for purposes of Public Finance and remains less dependent on foreign financial markets. In such a way, 7 issues of saving certificates allowed borrowing more than 41 million LTL at an annual interest rate of 2.5-2.9 percent only in less than one month (Ministry of Finance of the Republic of Lithuania, 2012).

The biggest advantage of the relations between the state and its citizens, based on social partnership, would be the possibility to avoid the extreme form of "dialogue", i.e. strikes or even riots of the citizens, during which they express their dissatisfaction with one or other government decision and often force to amend the already made, and perhaps even needed, decisions. One of the most severe examples of the absence of dialogue between the state and the citizens are the recent events in Greece, where vital actions in the state's financial area were met by massive strikes of the residents'.

The relations between the state and the companies in the discussed model, when state takes care and manages not only the public, but also the companies' finance, may be also based on social partnership and equality. In this case, it may be wise paying attention to the idea of Stiglitz (2011): "we must dispose myth that reducing the deficit will restore the economy. You don't create jobs and growth by firing workers and cutting spending. The reason that firms with access to capital are not investing and hiring is that there is insufficient demand for their products. Weakening demand - what austerity means - only discourages investment and hiring".

During a period of economic recession, the companies could voluntarily and responsibly assume a part of the state's financial burden. This could be done by retaining workplaces, this way reducing unemployment and rescuing the public finance system from the significant additional expenses (Table 1). The companies which have financial reserves, if needed, could lend to the state so that the state could finance the public functions without borrowing money from the international markets. The state, in turn, could treat companies as social partners aiming to create more favourable environment for business. The survey of Estonian companies acting in Lithuania disclosed that "the most unfavourable factors when doing business in Lithuania are: bureaucratic environment (82 proc.), Lithuanian business ethics (76 proc.), tax environment (71 proc.), the level of corruption (66 proc.), and legal framework (61 proc.)“(Fuks, 2012).

These areas might be used as guidelines for creating better business environment in Lithuania to ensure better macroeconomic results and on the same hand influence sustainability of state finance.

Summing up, it could be stated that, if to approach the state finance from a broader perspective that it is currently done, the stability of the state's financial system could be reached using alternative methods, which so far have not been tried out to the extent of the state. Namely, responsibly assuming and dividing the financial burden in times of economic and financial crises. Then the priorities in the state's finance management change, and it becomes interested to encourage its citizens and companies to become financially stronger and more prosperous. This is directly related to the collection of budget revenue and the funding of Public Functions.

\section{Conclusion}

In a face of globalization and currently experienced economic recession, aiming to ensure sustainability of state finance, it is expedient to broaden the concept of state finance so that it would cover both public and private finance. State finance might be defined as the total of public, 
corporate, and household finance, and the system of its collection, allocation, and use.

Broader concept of state finance would allow involving companies and residents into the system of financial management making it possible to use financial resources of such subjects and ensure financial sustainability of a state in a face of financial crisis.

After broadening the circle of financial subjects of a state, relationship between such subjects shall be based on social partnership; this will enable establishing longterm sustainability of state finance.

When relationship between state subjects is based on social partnership, residents and companies of a state might to certain extent "dump" the impact suffered by state finance in periods of financial instability. Then the state would not have to stand alone with enough limited fiscal policy measures; residents could live for renting their savings, and the companies would not reduce the number of employees taking a part of financial burden from the state.

Involving private subjects into state finance yet makes it possible to reduce the pressure of borrowing in foreign markets. This is because of private subjects possess enough finance to lend it to the state for refinancing previous debts in 2012-2013. By this way, a part of foreign borrowing may be transferred to 2014-2015, when the state will not have to pay foreign debts.

The use of domestic borrowing allows significant reduction of borrowing costs (due to the difference of interest rates), and positively affects domestic consumption that, in turn, contributes the economic growth of a state.

\section{REFERENCES}

1. Buškevičiūtè, Eugenija. Viešieji finansai [Public finance]. Kaunas: Technologija, 2008.

2. Jasinavičius. Rimvydas,; Ganiprauskas. Vidmantas, „The Impact Of Household Lending And Government Debt Instruments On The Lithuania's Economic Welfare" 16-17 Nov. 2011 International Scientific Conference "Whither Our Economies": 182-187 <http://www.mruni.eu/mru_It_dokumentai/fakultetai/ekonomikos_ir finansu_vadymo_fakultetas/konferencijos/woe/SESSION-2.pdf $>$.

3. Fuks, Erika. „Estonian capital company in Lithuania would like to see anything other than qualification“. DELFI. 9 Feb. 2012 $<$ http://verslas.delfi.It/business/estisko-kapitalo-imones-lietuvojepasigenda-visko-isskyrus-darbuotoju-kvalifikacijos.. ? $i d=55265119>$.

4. Jurgutis, Vladas. Finansu mokslo pagrindai [Fundamentals of Finance Science]. Kaunas: Šviesa, 1938.

5. Hillman, Arye L. Public finance and public policy: responsibilities and limitations of government. 2nd ed. Cambridge: Cambridge University Press, 2009.

6. Rakauskienè, Ona Gražina. Valstybès ekonominè politika: (fiskaliné, užsienio prekybos ir socialinè politika) [State Economy Policy (fiscal, foreign trade and social policy)]. Vilnius: MRU Leidybos centras, 2006.

7. Republic of Lithuania. Law on budgeting. 30 July 1990 (I-430). Vilnius. <http://www3.Irs.It/pls/inter3/dokpaieska.showdoc_l?p_id $=416012>$.

8. Republic of Lithuania. Ministry of Finance. 2011 will be borrowed half 2010 amount <http://www.finmin.lt/web/finmin/2011skol>.

9. Republic of Lithuania. Ministry of Finance. In 2012 State borrowing leads to earlier commitments. <www.finmin.lt>.

10. Republic of Lithuania. Ministry of Finance. Results of the Government savings notes emission, 2012 <http://www.finmin.It/ web/finmin/vyriausybes_vertybiniai_popieriai/tt_rez>.

11. Republic of Lithuania. The Securities Commission. Population survey of financial literacy, $2009<$ http://www.vpk.lt/lt/vpkpranesimai/investuotoju-svietimas/14093/>.
12. Schinasi, Garry J. "Understanding Financial Stability: Towards a Practical Framework." International Monetary Fund. 2007. <http://www.imf.org/external/np/seminars/eng/2006/mfl/gjs.pdf>.

13. Stiglitz, Joseph E. Economics of the public sektor. 3rd ed. New York/London: W.W.Norton, 1999.

14. Stiglitz, Joseph E. "Taming Finance in an Age of Austerity”. Project syndycate. 8 Jul. 2010. <http://www.project-syndicate.org/ commentary/stiglitz127/English>.

15. Stiglitz, Joseph E. „How to put America back to work“. Politico. 9 Jul. $2011<$ http://www.politico.com/news/stories/0911/62847.html \#ixzz1|12HoQ|6>. 